Original paper

DOI: 10.2478/agri-2021-0006

\title{
RAPID IDENTIFICATION OF RICE MACRONUTRIENT CONTENT IN SALINE SOILS USING SMARTPHONE CAMERA
}

\author{
ADITYA NUGRAHA PUTRA, ALBERTH FERNANDO SITORUS, QUID LUQMANUL HAKIM, \\ MARTIANA ADELYANTI, ISTIKA NITA AND SUDARTO
}

University of Brawijaya, Malang, Indonesia

Putra, A.N., Sitorus, A.F., Hakim, Q.L., Adelyanti, M., Nita, I. and Sudarto (2021). Rapid identification of rice macronutrient content in saline soils using smartphone camera. Agriculture (Pol’nohospodárstvo), 67(2), 61-75.

\begin{abstract}
Indonesia's rice production has decreased by $6.83 \%$ (on average) in the last five years (2015-2019) because of some factors. Salinity $(42 \%)$ is one of the leading factors that cause decreasing rice production besides climate change $(21 \%)$, drought $(9 \%)$, and other factors (28\%). The smartphone camera serves as an alternative technology to prevent macronutrient deficiencies due to salinity. This study used aerial photos from android with visible light (R, G, and B), and the image was taken from a height of $5 \mathrm{~m}$. The observation of macronutrient content in plant biomass was carried out using a free grid to adjust rice fields and saline soil. The formula was obtained from regression analysis and paired t-test between the biomass macronutrient and the extracted digital number of aerial photographs that have been stacked. The results showed that digital number (DN) from a smartphone was reliable to predict nitrogen $(\mathrm{N})$, phosphorus $(\mathrm{P})$, and potassium $(\mathrm{K})$ content in rice with formula $\mathrm{N}=0.0035 * \mathrm{DN}+0.8192\left(R^{2} 0.84\right), \mathrm{P}=0.0049 * \mathrm{DN}-0.2042\left(R^{2} 0.70\right)$, and $\mathrm{K}=0.0478 * \mathrm{DN}-2.6717\left(R^{2} 0.70\right)$. There was no difference between the macronutrient estimation results from the formula and the field's original data.
\end{abstract}

Key words: remote sensing, visible light, android, nitrogen, phosphorus, potassium, salinity

Rice is one of the world's vital food commodities in which productivity is predicted to decline in 2020 by $0.60 \%$ (USDA 2020). Based on the (World Agricultural Production.com, 2020), Indonesia ranked third in rice producers, with production reaching 36.5 million metric tons. In Indonesia, rice is an essential food commodity and is the primary foodstuff for the community. The increase in rice demand is not matched by increased production, which fell by $-6.83 \%$ (on average) from 2015 to 2019 (Central Bureau of Statistics 2020).

Compared to other problems that cause fluctuations in rice production, salinity still has a more severe impact - another case related to water availability. A study by (Iswari et al. 2016) mentioned that rice production is caused by drought at the re- search location, namely the Demak Regency, which resulted in crop failure of $0.629 \%$ in $2013,8.121 \%$ in 2014 , and $9.173 \%$ in 2015 . Another problem that has a similar effect to salinity is climate change. Rice production has decreased due to climate change in Indramayu Regency (Ruminta 2016), with an average decline of $21 \%$ to $40 \%$. Rice is often affected by salinity, reducing $42 \%$ production (Ahmed \& Haider 2014). Rice can adapt to almost any environment from lowland to highland. In Indonesia, rice cultivation is carried out in various lands, including wetlands in lowland rice fields, dry land, upland rice fields, and peatlands (Utama 2015). A study by Mardiansyah et al. (2018) stated that the Ciherang variety has moderate salinity tolerant characters. The Inpari 32 variety is an inbred from the selec-

Aditya Nugraha Putra (*Corresponding author), Soil Science Department, Faculty of Agriculture, University of Brawijaya, Malang, Indonesia. E-mail: aditya.n.putra@ub.ac.id 
tion results of the Ciherang variety, and Inpari 42 is a salinity tolerant variety (Agricultural Research and Development Agency, 2019).

Soil salinity shows the concentration of dissolved salt in the soil (Sembiring \& Gani 2010). Salinity occurs due to (1) the high intake of water containing salt, for example, due to seawater intrusion, (2) higher evaporation and evapotranspiration than precipitation (rainfall), and (3) soil parent material containing salt deposits (Rachman et al. 2018). Lowland rice production due to salinity stress can cause a decrease in production. The effect of salinity on crops includes osmotic pressure, nutrient balance, and $\mathrm{NaCl}^{-}$salts' toxic impact on saline soils that can disrupt the nutrient balance because certain nutrients are excess or reduced. Potassium is exchangeable, which means a decrease in these elements' availability affects other nutrients crops (Setiawan \& Herdianto 2018). The salinity symptoms in rice crops begin with dry leaf tips, reduced tillers, root length, crop height, shoot dry weight, and root weight. Salinity suppresses crop growth processes with effects that inhibit cell enlargement and division, protein production, and the addition of crop biomass. Crops that experience salt stress do not respond directly to damage, but growth is depressed and changes slowly. Excess $\mathrm{Na}^{+}$in crop cells directly damages membrane systems and organelles, causing abnormal growth and development before crop death (Sayed \& Sayed 2013).

The use of smartphones to identify the macronutrient content of biomass is interesting to study. This technology has potential because many people have used smartphones, have high resolutions, and can be used quickly. One of the most widely used smartphone platforms is an android ( $>80 \%$ smartphone user use). Android is a Linux-based operating system for smartphones that includes an operating system, middleware, and applications (Safaat 2011). Some android cameras' sensors are ambient light sensors, temperature and humidity sensors (Maulana \& Setiawan 2018).

In the previous research, Setiawan and Herdianto (2018) created a mobile application that could analyse and recommend the need for nitrogen in rice plants based on the rice leaves' colour. In this application, a set of process stages for image processing and classification is implanted. It is used to analyse the colour of rice leaves captured via an android camera. Image processing is a feature extraction of red, green, and blue (RGB) values to obtain features in leaf colour images. From the accuracy testing results, the application accuracy rate in analyzing and recommending nitrogen needs on average is $66.67 \%$.

This study aims to implement an android camera to monitor macronutrient content in saline fields. The salinity level in a plot/landscape is considered a common problem. The previous study conducted smartphone camera use (Astika et al. 2011), macronutrient analysis, and salinity analysis (Grattan \& Grieve 1998). It is necessary to have a technological breakthrough that can "photograph" the variability macronutrients in the salinity area. The breakthrough is the use of terrestrial cameras. The implementation of agricultural precision is planned for modern technology by utilizing industrial era 4.0 technologies such as terrestrial cameras. Therefore, this study measures how accurate terrestrial cameras are in analyzing salinity problems in rice crops. Hopefully, this study can support the government's food security program (NAWACITA) and SDGs.

\section{MATERIAL AND METHODS}

\section{Research location}

The research activity was carried out in the rice fields in the Jabon district, Sidoarjo Regency, and East Java (Figure 1). Jabon district is located in a lowland, with coordinates of $112^{\circ} 70^{\prime} 36.17^{\prime \prime}$ $-112^{\circ} 87^{\prime} 33.13^{\prime \prime}$ East longitude and $7^{\circ} 49^{\prime \prime} 40.01^{\prime \prime}$ $-7^{\circ} 57^{\prime} 83.45^{\prime \prime}$ South latitude. The study area has an annual rainfall ranging from $1,300-1,700 \mathrm{~mm}$ per year, with the number of rainy days ranging from 80-120 rainy days per year. The average air temperature per year in this area ranges from $21-34^{\circ} \mathrm{C}$ with a relative humidity level of $\pm 76 \%$ (Climate-Data.org). There are three reasons why choosing a small place like Sidoarjo Regency as the research location, namely 1) It is easier to generate basic data for the algorithm; 2) The large image capacity of the smartphone camera becomes inefficient if applied to a large area, and 3) Unique landforms. The Jabon Subdistrict area is formed from the river and sea sedimentation or fluvio-marine. 
One of the characteristics of this landform is high salinity because the material contains salt deposits. Many people take advantage of it by cultivating rice, although the harvest in recent years has decreased. The same landform character is found in Central Java, Rembang Regency. It is also formed from the sedimentation of rivers and seas. Erosion material is deposited by rivers on the coast and combined with material carried by ocean waves (Wulan et al. 2016).

Jabon district is located in a coastal lowland area, which topography condition is influenced by fluvio-marine sediment and alluvium material (Marsoedi et al. 1997). The soil types in the Jabon district include Typic Hydraquents (Soil Survey Staff 2014). The rice field is an area of 1,883.86 ha, or $23.05 \%$ (from the total area). Jabon district consists of two alluvial and marine landscapes. The alluvial landform with the alluvial plain sub-landform is in the western part of 2,417.01 ha or $29.6 \%$. Marine landform with plains tidal sub-land is east of Java Island, covering $5,756.34$ ha or $70.4 \%$ (Marsoedi et al. 1997).

\section{Material}

A smartphone camera took the image in RGB format with 48 megapixels. This terrestrial camera had 4GB RAM and a 4,000 mAh battery. The image had a size of $4,000 \times 3,000$ pixels. Another tool used was a $5 \mathrm{~m}$ long pole as a vertical photo-taking tool. Then there was the Gimbal for the terrestrial camera stabilizer (Astika et al. 2011).

\section{Field observation}

The research location was determined based on the initial salinity analysis with an Electrical Conductivity value of $9.6 \mathrm{mS} / \mathrm{cm}$ and exchangeable $\mathrm{Na}$ of $1.8 \mathrm{cmol} / \mathrm{kg}$. This study was located in two transects. The length of Transect 1 was $\pm 4 \mathrm{~km}$, and Transect 2 was $\pm 3.4 \mathrm{~km}$. Transect 1 was $316-817$ meters, and Transect 2 was 104-718 meters, where each transect had ten observation points. The salinity source's distance was $10.65 \mathrm{~km}$ - point determination based on a free grid (Rayes 2007). Transect 1 consisted of observation points 1a to $10 \mathrm{a}$, which had a distance of 11.2 to $13.4 \mathrm{~km}$ from the salinity source. Additionally, transect 2 consisted of observation points $1 \mathrm{~b}$ to $10 \mathrm{~b}$, which had a 10.3 to $13.5 \mathrm{~km}$ distance from the salinity source.

The point determination could be seen from soil analysis results (saline indication) and the coast distance. The rice and soil samples were taken using an

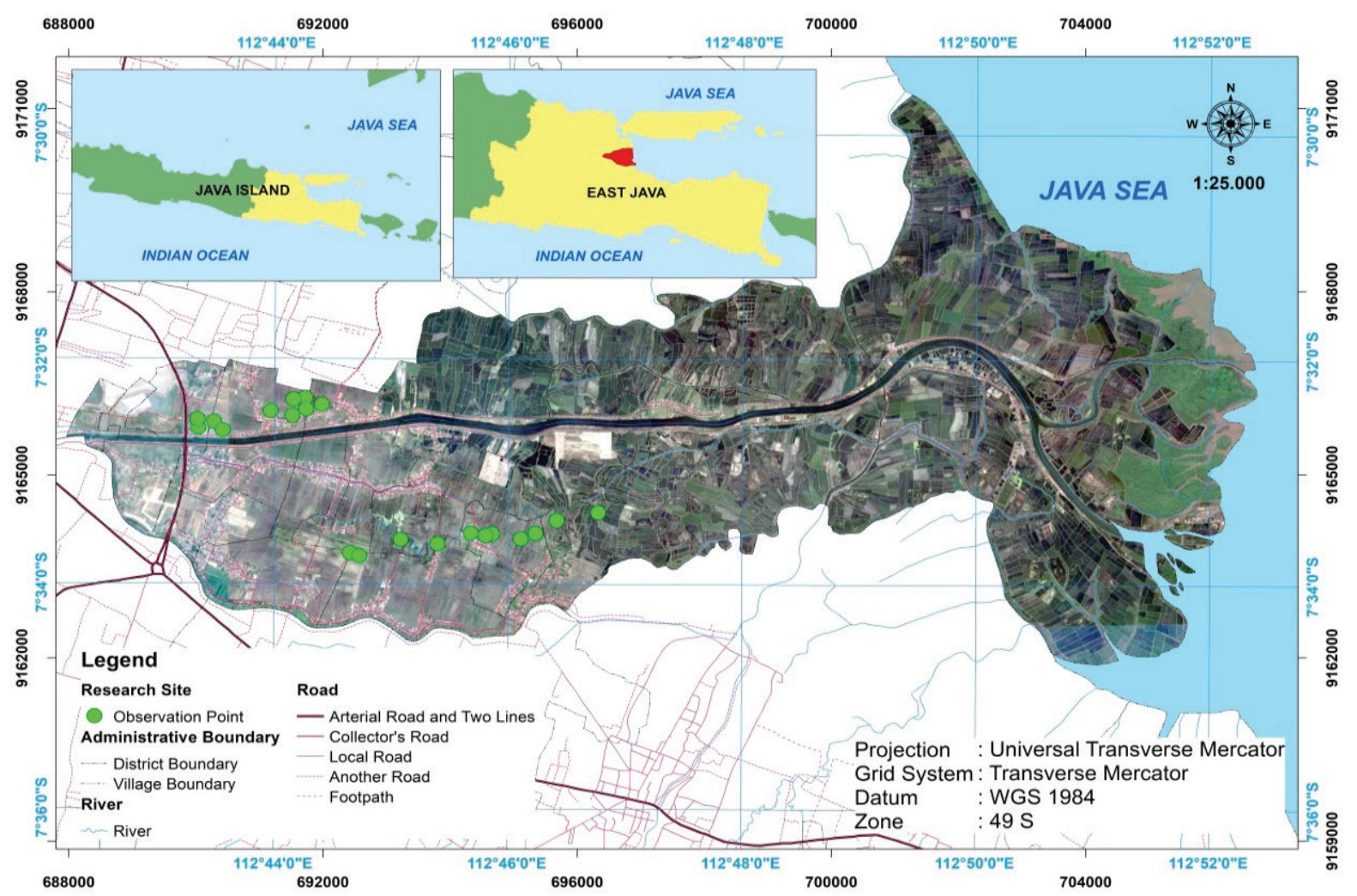

Figure 1. Distribution of research observation points 
active field survey method by constructing transects through the ArcGIS 10.3 application. Determination of the sampling point is taken based on field conditions / without a rigid grid and directly tagged to take the location's coordinates. Determination of observation points is done by purposive randomized sampling (Rayes 2007). The soil and rice sampling methods are described in "Soil and crops sampling" section (page 65). The research location was determined based on the age of the crops (in the vegetative phase). The age of rice crops obtained in the survey activity was between the ages of 41 to 56 DAP (days after planting). The plants were classified into the vegetative phase of class 2 , rice crops aged 41-64 DAP from the age data. Detection of rice crops in rice fields with a good image is in the vegetative phase 2 (LAPAN 2015). This stage also involved the preparation of tools and materials. Then the tools needed for the field survey were prepared, such as a trowel, SPAD (chlorophyll meter), dreadlocks, 5 meter long sticks, administrative maps of Jabon Regency, and other supporting maps (Rayes 2007).

\section{Photo-taking using smartphone camera}

The tool used was a smartphone camera with 48 megapixels and visible light wavelengths (red, green, and blue). A gimbal smartphone camera supported the camera to stabilize, and the images were taken from a height of $5 \mathrm{~m}$. The photoshoot was carried out in the rice field with an area, and the land adapted to the existing land with varying levels of leaf colour (Astika et al. 2011). The gimbal stabilizer can stabilize the movement and disturbance of the wind because the actuator system in the gimbal design uses a servo motor (Fahmizal et al. 2018). Servo motor is an electrical device used in machines that function to push or rotate objects with high precision control in angle, acceleration, and speed. The angle of elevation of the gimbal will be controlled stably (Suryana 2018).

The first step in taking photos using a smartphone, apart from making sure the camera is functioning correctly, is paying attention to suitable weather conditions. Overcast skies or the hot sun will affect the image. Smartphone photos require side lap, overlap, and image height settings so that errors that occur due to movements such as tilt and poor lighting can be avoided (Syauqani et al. 2017). The difference in the tilt and angle of sunlight, shooting is carried out simultaneously at 10:00 a.m. and a minimum height of 5 meters for smartphone camera use. Research conducted by Simanungkalit
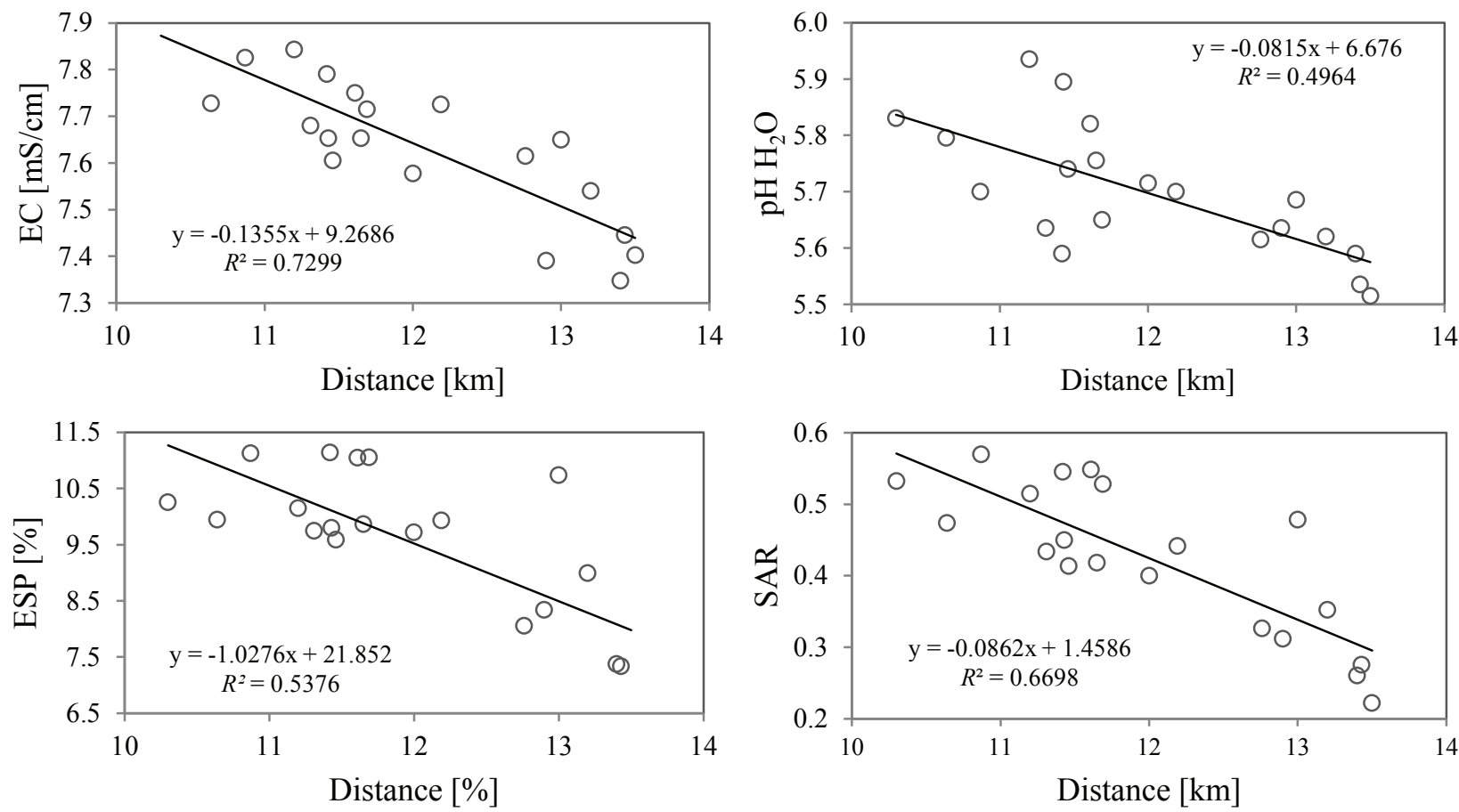

Figure 2. Graph of soil salinity indicator. EC -Electrical Conductivity; ESP - Exchangeable Sodium Percentage; SAR - Sodium Adsorption Ratio; $\mathrm{pH} \mathrm{H}_{2} \mathrm{O}$ based on the distance from the salinity source 
et al. (2019) found that smartphone photos obtained from images taken at 10:00 a.m. had an aerial photo accuracy rate of above $95 \%$ in the perfect category.

\section{Soil and crops sampling}

The survey activities were carried out by taking soil and crop samples. The soil and crop (leaf) samples were taken before or after aerial photographs on the same day. This step was taken so that the soil samples taken did not undergo significant changes in the field conditions. Real-time sampling was also carried out so that the resulting data can have high accuracy values. The soil sampling taken was a layer of the rice root area. The soil sampling was done on topsoil using the undisturbed soil sampling method (Putra \& Nita 2020). The soil sampling was taken from a depth of $0-0.2 \mathrm{~m}( \pm 1 \mathrm{~kg})$ (Vadas et al. 2006). The sampling of rice biomass was carried out by taking part in the leaves. The determination of soil and crop sampling points based on field conditions/without rigid grids and directly tagged to retrieve location coordinates using GPS. The decision of the observation points was carried out by purposive randomized sampling (Rayes 2007). The composite soil sampling and rice leaf samples were conducted for laboratory analysis to obtain levels of nitrogen (Bremner 1996), phosphorus (Bray \& Kurtz 1945) and potassium (Zakiyah et al. 2018) as macronutrients.

\section{Salinity parameter analysis}

In identifying macronutrients in rice crops in saline soils, salinity parameters must be considered. Salinity analysis was evaluated using the percentage of sodium exchange (ESP), soil $\mathrm{pH}$, electrical conductivity (EC), and sodium adsorption ratio (SAR) (Djuwansah 2013). This parameter is called the salinity indicator. Salinity parameter criteria are exchangeable sodium percentage (ESP) $<15 \%$ (Gupta \& Sharma 1990), soil $\mathrm{pH}<8.5$ (Amran et al. 2015), sodium adsorption ratio (SAR) $<13$ (Robbins 1984), and electrical conductivity (EC) is $2-4$ or $>4 \mathrm{mS} / \mathrm{cm}$ (Rhoades et al. 1989) in soil. Saline soil is different from saline-sodic and sodic soil. Saline-sodic has criteria of EC $>4 \mathrm{mS} / \mathrm{cm}, \mathrm{ESP}>15 \%$, and $\mathrm{pH}>8.5$. Sodic soil has criteria of EC $<4 \mathrm{mS} / \mathrm{cm}, \mathrm{ESP}>15 \%$, and $\mathrm{pH}>8.5$ (Sipayung 2003).

Image pre-processing and digital number extraction

The pre-processing of smartphone aerial photos was an initial data processing process. There were several pre-processing stages performed (Muñoz \& Kravchenko 2011). The first stage was rectifica-

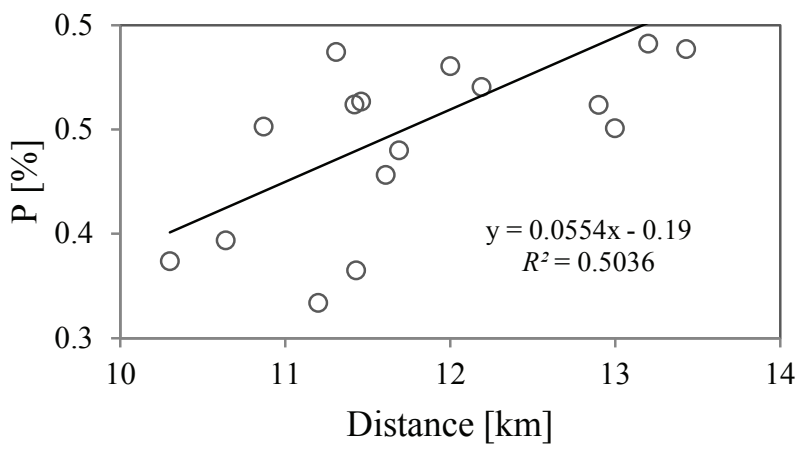

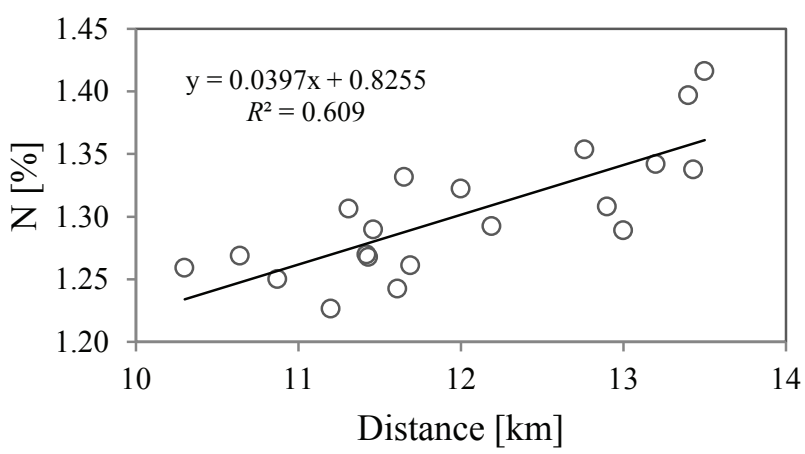

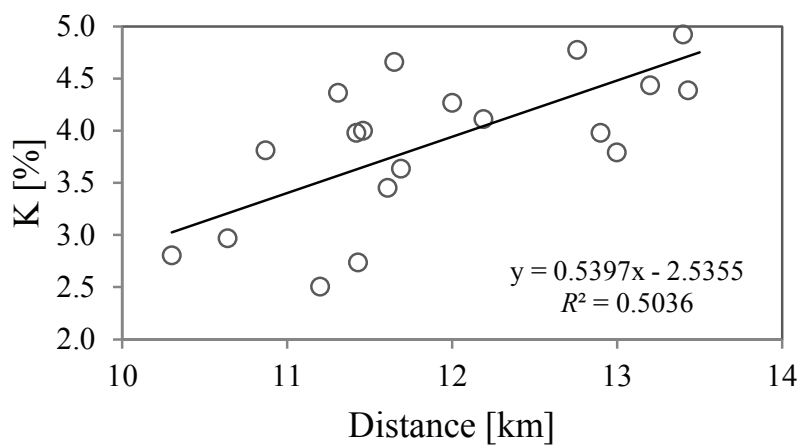

Figure 3. Plant biomass analysis result and the distribution based on distance from saline source Note: $\mathrm{N}$ - nitrogen; $\mathrm{P}$ - phosphorus; $\mathrm{K}$ - kalium 
tion. The second step is to extract digital numbers in ArcGIS 10.3 using the Extract Value to Points Tool (Putra \& Nita 2020). This tool is used to obtain the digital number of each pixel at the raster observation point (Dell 2009). Digital numbers are RGB values because rasters are made up of red, green, and blue waves. In this study, the digital number value is the total value of the red, green, and blue waves in one pixel (RGB combination). The digital number transformation results were continued with statistical analysis of correlation and regression using $R$ software and then compared with laboratory data correlated with rice crops.

The point of taking the digital number reclaimed aerial photo made diagonally. In one aerial photo, there were five digital number value retrieval points. Each DN value retrieval point was three replications (15 points in total), then averaged into one aerial photo's value (Astika et al. 2011). The smartphone camera aerial photos were entered into the ArcGIS 10.3 application. The rectification was carried out with the coordinates of the rectification coordinates in each aerial photograph corner. It was then cor-

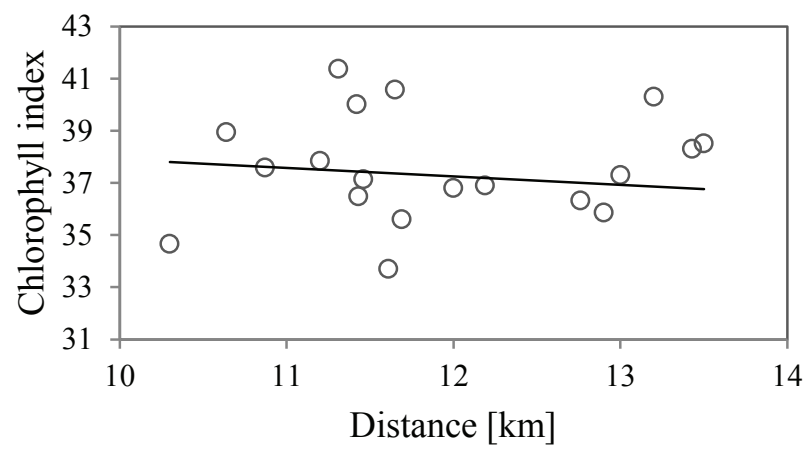

Figure 4. Graph of chlorophyll index

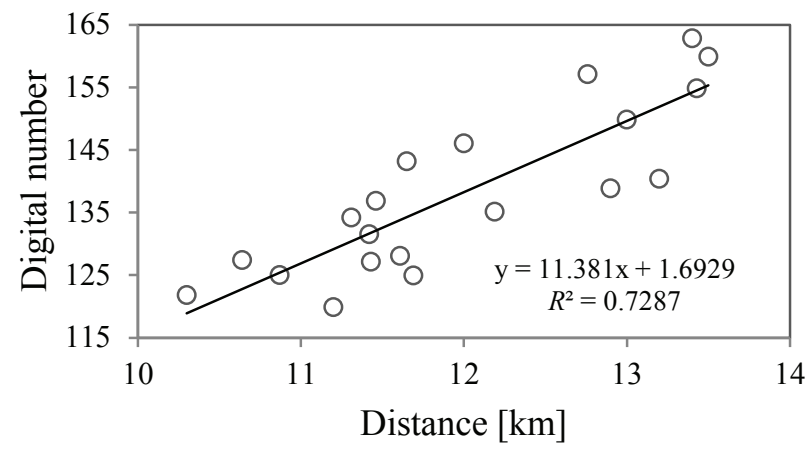

Figure 5. Digital number distribution based on the distance of the saline source rected, and the digital number extraction was started by adding an improved aerial photo.

Moreover, the digital number extraction was carried out. The extraction of digital numbers on a smartphone camera was carried out using each rectified photo, and then a sampling point was entered. This study was conducted using visible (red, green, blue) channels obtained through shooting using smartphone cameras.

\section{Statistical analysis}

Initially, the laboratory data results and the normality test result for potato production were analyzed using R studio by the Shapiro-Wilk method (Royston 1992). The correlation test was used to determine the closeness of the relationship between variables and the direction of the relationship (Putra $\&$ Nita 2020) The correlation coefficient value (r) was compared to the r-table (Bewick et al. 2003).

Formulation and interpolation of macronutrients deficiency in saline soil

The equation was used to estimate macronutrients (nitrogen, phosphorus, and potassium) of rice crops in salinity stress. Moreover, the resulting equations were associated using an aerial photo with a raster calculator on ArcMap 10.3 in ArcToolbox on the Map Algebra tool (Lubis 2011). The resulting interpolation estimated macronutrients (nitrogen, phosphorus, and potassium) in rice biomass.

\section{Accuracy assessment}

The validation test used a paired t-test to verify the correctness or certainty of a model. The reliability test using R studio aimed to determine whether model consistency accuracy - validation using the T-pair test (Montolalu \& Langi 2018).

\section{RESULTS}

\section{Soil salinity analysis results}

Based on Figure 2, the values of electrical conductivity (EC), SAR, ESP, and $\mathrm{pH} \mathrm{H}_{2} \mathrm{O}$ are getting bigger and closer to the source of salinity. The image is included in the classification of moderate salinity values. The electrical conductivity obtained in this study ranged from 7.35 to $7.92 \mathrm{mS} / \mathrm{cm}$. According to Sipayung (2003) classification based on electrical conductivity values, moderate salinity is rated 
at $4-8 \mathrm{mS} / \mathrm{cm}$, where many plants are affected. It includes control in SAR because the value is $<13$, ESP includes control because all points have ESP values $<15 \%$, and $\mathrm{pH}<8.5$. That value corresponds to the saline soil.

The chemical properties used as criteria for saline soils are characterized by soil EC more than $4 />4 \mathrm{mS} / \mathrm{cm}$, EC (Electrical Conductivity) $<15 \%$, and $\mathrm{pH}<8.5$ (Pardo 2010). The salinity indicator consisting of EC, $\mathrm{pH} \mathrm{H}_{2} \mathrm{O}$, ESP, and SAR showed an increase in the value of each indicator as the distance from the saline source got closer (Figure 2). The EC values at all observation points increased to $7.4 \mathrm{mS} / \mathrm{cm}$ at a distance of $13.5 \mathrm{~km}$, then increased to about $7.9 \mathrm{mS} / \mathrm{cm}$ at a distance of $10.5 \mathrm{~km}$. The same pattern of increase also occurred in $\mathrm{pH} \mathrm{H}_{2} \mathrm{O}$ and SAR. Soil $\mathrm{H}_{2} \mathrm{O}$ pH increases from about 5.5 to almost 6 as the salt sources are closer to each other. Another indicator is that the SAR increased from $0.2 \%$ to $0.6 \%$, and the ESP increased from 6 to around 10. Therefore, the closer to the saline source, the higher the salinity level. This condition causes the area near the source of salinity to become an area of high salinity flow to crops.

\section{Macronutrient biomass analysis results}

Analysis of nitrogen, phosphorus, and potassium biomass:

The laboratory analysis of nitrogen, phosphorus, and potassium crops (leaves) showed that the total nitrogen, phosphorus, and potassium levels of rice crops decreased towards the saline source at the observation point. The results of the study of the total nitrogen, phosphorus, and potassium values of rice crops showed a decrease as the distance began to get closer to the source of salinity (Figure 3). Salinity is very influential, where the higher the salinity value causes inhibition of nutrient absorption for crops. Salinity interferes with crops' nutrient uptake in two ways. First, the ionic strength of the substrate, regardless of its composition, can influence nutrient uptake and translocation. Second, salinity interferes with plant mineral relationships by reducing nutrient availability through competition with ions (Monica et al. 2014).

\section{Leaf chlorophyll index}

Chlorophyll is one of the factors to determine the status of nutrients in leaves. Figure 3 has the lowest chlorophyll value of 30.8 units/SPAD, and the highest is 41.38 units/SPAD. According to Prabowo et al. (2018), chlorophyll measurement results with SPAD values can be categorized into three criteria, namely low $(<50)$, medium $(50-53)$, and height $(>53)$. The chlorophyll in this study had a SPAD value of $<50$ came in the low category. The difference in rice chlorophyll in various varieties was due to crops' ability to adapt to different salinity conditions.

As shown in the graph in Figure 4, the chlorophyll's value does not increase or decrease significantly. The salinity source's far and proximity do not affect the increase or decrease in chlorophyll's value. This condition is due to the difference in the age of crops and rice varieties used.

The average age of crops at a distance of $13.4 \mathrm{~km}$ to $11.2 \mathrm{~km}$ from salinity source was $50 \mathrm{DAP}$ (the day after planting), with the youngest crops age 42 DAP. Besides, in on-point observation, with a distance of $13.5 \mathrm{~km}$ to $10.3 \mathrm{~km}$ from the salinity source, the average age of crops was 54 DAP with the oldest age of 58 days after planting and the youngest of 50 DAP. The varieties used at all observation points were Ciherang, Inpari 32, and Inpari 42 varieties. The chlorophyll index was reviewed from varieties. The average value of chlorophyll in the Ciherang variety was 36.1 units, Inpari 32 variety was 37.6 units, and Inpari 42 was 38 units. According to (Banyo et al. 2013), in terms of crop life, crops with a more extended planting period cause a higher chlorophyll concentration than plants that grow faster in the vegetative phase. According to (Muyassir 2012), crop age affects the value of chlorophyll in leaves. Mardiansyah et al. (2018) stated that the Ciherang variety has moderate tolerant characters to high salinity. Inpari 32 is an inbred variety from the Ciherang selection, and Inpari 42 is a salinity tolerant variety (Suhartini \& Zulchi 2018). Their results stated that salinity did not affect the crop's chlorophyll levels (Nurgayah \& Irawati 2017).

\section{Digital number extraction}

In this study, the digital number (DN) used is a combination of RGB. Extraction of digital numeric values is taken from the total values of the red, green, and blue pixels visible in the aerial pho- 
to. Pixels (picture elements) are the minor element points in a photo. The numeric number (1 byte) of a pixel is called the digital number (DN) (Efendi 2012). The use of smartphones can be implemented independently (stand-alone) by storing data on the mobile device (for simple applications) (Gunita et al. 2013). The smartphone's camera uses visible RGB (red, blue, and green) electromagnetic waves. Unlike terrestrial cameras, UAVs, drones, and others, the DN value uses visible light (RGB), NIR or SWIR, or Red Edge. However, if used a vegetation/ soil index, the name is an index number, not a digital number (Bernardi et al. 2017). The use of smartphones is developing satellite imagery and UAV research with a higher level of precision. Salinity characteristics between locations are different, so it is necessary to use smartphones (Astika et al. 2011).

The digital number extraction is started with adding RGB photos. Then a digital number extraction is performed. Digital number extraction on a smartphone camera is done using each photo rectified and then inserted sampling point. In one aerial photo, there are five digital number value retrieval points. Each DN value retrieval point consists of three replays (15 points in total), then averaged to one aerial photo's value. The data of digital number extraction results through aerial photos utilizing smartphone camera obtain results with details based on Figure 5.
The highest digital number value is obtained at 162.8 , while the lowest at 119.4. The highest digital number value is obtained at 159.9 , while the lowest at 121.8. The digital number's value increases to point ten, the digital number value decreases. The closer the salinity of the source, the digital number values decrease (Figure 5).

\section{Statistical analysis result}

Normality test:

The observation variable carried out by the normality test can be said to be normal if the p-value is $p \geq 0.05$. The Digital Number smartphone camera has a normality test value of 0.236 . $\mathrm{N}$ total [\%] crops have a normality test value of 0.340 . Then, from the availability of nutrients in the biomass, namely nitrogen total [\%], crops have a normality test value of 0.340 , phosphorus total [\%] value of 0.601 , and potassium total [\%] value of 0.604 . From the availability of nutrients in the soil, namely nitrogen total [\%], the soil has a normality test value of $0.246, \mathrm{P}_{2} \mathrm{O}_{5}$ total $[\mathrm{mg} / 100 \mathrm{~g}]$ value of 0.614 and $\mathrm{K}_{2} \mathrm{O}$ total $[\mathrm{mg} / 100 \mathrm{~g}]$ value of 0.574 . EC $[\mathrm{mS} / \mathrm{cm}]$ has a normality test value of 0.627 . Salinity indicators can be seen from $\mathrm{pH} \mathrm{H}_{2} \mathrm{O}$ data has a normality test value of $0.734 ; \mathrm{pH} \mathrm{KCl}$ data has a normality test value of 0.530 , ESP value of 0.254 , and SAR value of 0.298 . All parameters data can be said to

$\mathrm{T}$ a

Correlation analysis of parameters with smartphone camera digital number

\begin{tabular}{|c|c|c|c|c|c|c|c|c|c|}
\hline & $\mathrm{DN}$ & Chlorophyll & $\mathrm{EC}$ & $\mathrm{pH} \mathrm{H}_{2} \mathrm{O}$ & ESP & SAR & $\mathrm{N}[\%]$ & $\mathrm{P}[\%]$ & $\mathrm{K}[\%]$ \\
\hline $\mathrm{DN}$ & 1 & -0.11 & -0.81 & -0.70 & -0.78 & -0.84 & 0.91 & 0.84 & 0.84 \\
\hline Chlorophyll & & 1 & 0.15 & -0.12 & 0.10 & 0.06 & -0.02 & 0.11 & 0.11 \\
\hline $\mathrm{EC}$ & & & 1 & 0.63 & 0.83 & 0.92 & -0.83 & -0.69 & -0.69 \\
\hline $\mathrm{pH} \mathrm{H}_{2} \mathrm{O}$ & & & & 1 & 0.55 & 0.60 & -0.71 & -0.84 & -0.84 \\
\hline ESP & & & & & 1 & 0.97 & -0.87 & -0.62 & -0.62 \\
\hline SAR & & & & & & 1 & -0.91 & -0.71 & -0.71 \\
\hline $\mathrm{N}[\%]$ & & & & & & & 1 & 0.87 & 0.87 \\
\hline $\mathrm{P}[\%]$ & & & & & & & & 1 & 1.00 \\
\hline $\mathrm{K}[\%]$ & & & & & & & & & 1 \\
\hline
\end{tabular}

Description: EC - Electrical Conductivity; ESP - Exchangeable Sodium Percentage; SAR - Sodium Adsorption Ratio; pH acidity. Note: $\mathrm{N}$ - nitrogen; $\mathrm{P}$ - phosphorus; $\mathrm{K}$ - kalium 
be expected because the value is more than 0.05. All parameters can be said to be expected so that they can be continued to the correlation.

\section{Correlation between salinity and biomass nutrient availability}

The correlation test between parameters and smartphone camera digital number values is presented in Table 1. The macronutrients (nitrogen, phosphorus, and potassium) and salinity indicators in rice crops based on the smartphone camera digital numbers are processed from smartphone regression test equations camera digital number values and the results of the analysis of crops and soil samples in rice crops in the field.

The equation used is the equations of smartphone camera digital numbers. Based on Table 1, the comparison results show that smartphone camera digital numbers calculate the r-value greater than the r-table (0.4438). It can be said that the DN smartphone camera value is increasing. The value of nitrogen, phosphorus, and potassium will also increase. The regression tests can be carried out and used to determine the nutritional estimates of nitrogen, phosphorus, and potassium in rice crops. In contrast, chlorophyll has a low correlation value and negative results on the DN smartphone camera. Chlorophyll has a lower calculated r-value, so the correlation result value cannot be performed for regression tests.

The macronutrients (nitrogen, phosphorus, and potassium) in rice crops based on salinity indicators such as $\mathrm{pH}_{2} \mathrm{O}, \mathrm{EC}(\mathrm{mS} / \mathrm{cm}), \mathrm{ESP}$, and SAR have processed the analysis of crops and soil samples in rice crops in the field. Based on Table 1, the comparison results show that the correlation between nitrogen, phosphorus, and potassium rice crops on the salinity indicators such as $\mathrm{pH} \mathrm{H}_{2} \mathrm{O}, \mathrm{EC}$, ESP, and $\mathrm{SAR}$ values is negative. It can be said that the higher the value of salinity indicators such as $\mathrm{pH}_{2} \mathrm{O}$, EC, ESP, and SAR will be inversely proportional to nitrogen, phosphorus, and potassium rice crops, namely decreasing. In comparison, chlorophyll has a low correlation value for controlling $\mathrm{pH}_{2} \mathrm{O}$, ESP, EC, and SAR indicators. Chlorophyll has a lower calculated r-value, so the correlation result value cannot be performed for regression tests.

Regression $\left(R^{2}\right)$ parameters nitrogen, phosphorus, and potassium total biomass rice using smartphone camera digital number.
The $R^{2}$ value is obtained from the regression formula in nitrogen, phosphorus, and potassium crops, which means the data is accurate. The regression equation in Figure 6 shows that the y-axis nitrogen, phosphorus, and potassium total [\%] in rice crops, and the $\mathrm{x}$-axis shows the smartphone camera digital number (DN) value, so nitrogen, phosphorus, and potassium total in rice crops are affected by the smartphone camera DN value. In Figure 6, values $0.0035(\mathrm{~N}), 0.0049(\mathrm{P})$, and $0.0478(\mathrm{~K})$ are the slopes that determine linear regression direction and $0.8192(\mathrm{~N}),-0.2042(\mathrm{P})$, and $-2.6717(\mathrm{~K})$ is intercept value. The slope value indicates a positive that the higher the $\mathrm{x}$-values than the greater the $\mathrm{y}$-value. The slope value also shows the rate of increase of nitrogen, phosphorus, and potassium total rice crops, an increase of nitrogen, phosphorus, and potassium the total rice crops increased by $0.0035(\mathrm{~N})$, $0.0049(\mathrm{P})$, and $0.0478(\mathrm{~K})$. In contrast, the intercept value refers to the initial calculation value, when the values $\mathrm{x}=0$, then nitrogen, phosphorus, and potassium total rice crops are $0.8192(\mathrm{~N}),-0.2042(\mathrm{P})$, and $-2.6717(\mathrm{~K})$, respectively.

The regression results have obtained the estimation of nitrogen, phosphorus, and potassium nutrients in rice crops. Nitrogen, phosphorus, and potassium data in rice crops in the field with estimated data nitrogen, phosphorus, and potassium using smartphone camera DN show values were not much different. The DN smartphone camera on each aerial photo after extraction produces pixels with red, blue, and green values converted in a DN value that can be used to guess the macronutrients of rice crops.

\section{Accuracy assessment (t-pair test)}

The estimation results using a smartphone were tested using a paired T-test to see the similarity of the laboratory data with the estimated $\mathrm{N}, \mathrm{P}$, and $\mathrm{K}$ nutrients for rice crops and salinity indicators. The estimated $\mathrm{p}$-value is lower than $p>0.05$, consisting of $\mathrm{N}, \mathrm{P}$, and $\mathrm{K}$, which are $0.58,0.81$, and 0.97 , respectively. The t-value also shows no difference between the results of laboratory analysis and estimates, which are $-0.45(\mathrm{~N}), 0.19(\mathrm{P})$, and $0.11(\mathrm{~K})$, respectively. The paired t-test shows that the calculated $\mathrm{t}$-value is smaller than the $\mathrm{t}$-table value $(0.68)$ for $\mathrm{N}, \mathrm{P}$, and $\mathrm{K}$. This shows no difference between the results of macronutrient analysis from the labo- 
ratory and the estimation results using a smartphone.

\section{DISCUSSION}

Smartphones can be used to identify macronutrient biomass in rice with an estimated value that does not differ from laboratory analysis results. DN smartphone can be used to predict $\mathrm{N}, \mathrm{P}$, and $\mathrm{K}$ crops. A study by (Amri \& Sumiharto 2019) shows that a smartphone system can detect nitrogen, phosphorus, and potassium nutrients in rice fields in the Special Region of Yogyakarta. In addition, based on LPT Bogor research, the results of the detection of nutrient levels of nitrogen, phosphorus, and potassium showed an average detection accuracy of $70.65 \%$ (N 94.98\%, P 50.84\%, and K 66.14\%). The best formula that results from the research results is NTotal $=0.0035 * \mathrm{DN}+0.8192\left(R^{2} 0.84\right)$, PTotal $=0.0049$ $* \mathrm{DN}-0.2042\left(R^{2} 0.70\right)$ and KTotal $=0.0478 * \mathrm{DN}$ $-2.6717\left(R^{2} 0.70\right)$, respectively (Figure 6).

Salinity affects the concentration of macronutrients in crops, reduces the accumulation of nitrogen in crops, phosphorus concentration, and decreases the accumulation of $\mathrm{K}^{+}$in crop tissues. This equation shows that every 1 unit increase in the value of the DN Smartphone camera will have a positive effect on macronutrients (nitrogen, phosphorus, and potassium) of $83.7 \%$ (nitrogen), 70.34\% (phosphorus), and $70.29 \%$ (potassium). In other words, the positive effect shows that the higher the DN value of the Smartphone camera, the more macronutrients (nitrogen, phosphorus, and potassium) increase. Jabon Regency has a fluvio-marine landform formed from a sedimentation process from a mixture of river sediment (alluvium) and marine sediment (marine). Jabon was previously an ocean that has become land so that the area still contains salt deposits in the underground part.

The metabolic imbalance caused by ion $\left(\mathrm{Na}^{+}\right)$ poisoning causes nutrient deficiency (nitrogen, phosphorus, and potassium). The destructive effect of salinity on plants is related to the high osmotic pressure of water, an imbalance between $\mathrm{Na}$ and $\mathrm{K}$, $\mathrm{Ca}, \mathrm{Mg}$ ions, and decreased uptake of nitrogen and phosphorus (Grattan \& Grieve 1998). Salinity seems to affect two processes, namely water relations, and ionic relations. During initial exposure to salinity, the crops experience water pressure, which reduces the development of leaves. During long-term salinity exposure, crops experience ionic stress, causing three potential effects on crops: reducing water po-

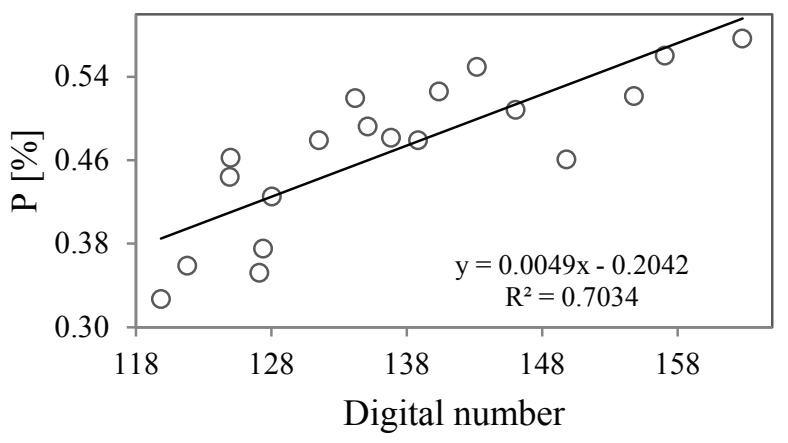

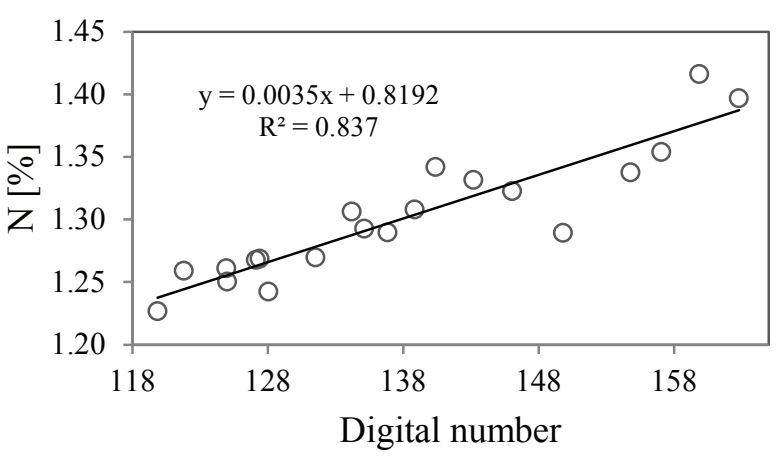

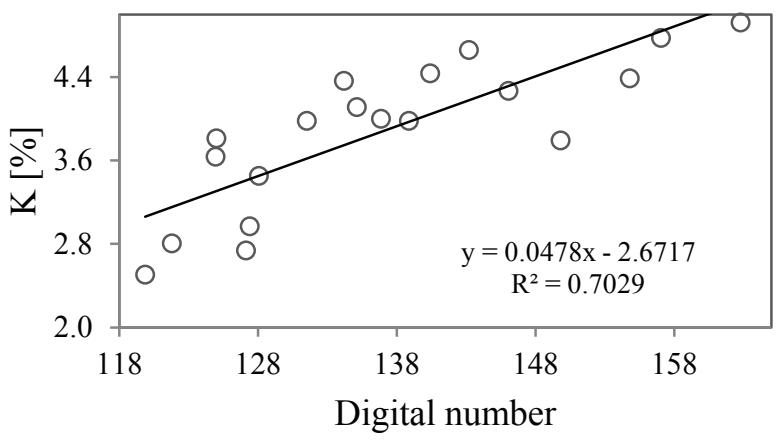

Figure 6. Regression graphic of nitrogen, phosphorus, and potassium total crops with DN smartphone camera Note: $\mathrm{N}$ - nitrogen; $\mathrm{P}$ - phosphorus; $\mathrm{K}$ - kalium 
tency, direct toxicity of any absorbed $\mathrm{Na}$ and $\mathrm{Cl}$, and disruption to the absorption of essential nutrients (Flowers \& Flowers 2005). Salinity causes severe damage to many cellular and physiological processes, including photosynthesis, nutrient absorption, water absorption, root growth, and cell metabolism, which leads to decreased results (Darwish et al. 2009). Soil control affects the absorption of nitrogen, phosphorus, and potassium in crops. The specific effects of soil control on crop metabolism, EC in leaf aging, are associated with $\mathrm{Na}^{+}$and $\mathrm{Cl}^{-}$ion accumulation and decreased $\mathrm{K}^{+}$. Salinity associated with excess $\mathrm{NaCl}$ affects crop growth and yield by suppressing water and mineral absorption and normal metabolism (Al-Karaki 2000). According to Sipayung (2003), salinity inhibits the growth of roots, stems, and leaf area, as well as metabolic imbalances caused by ion poisoning $\left(\mathrm{Na}^{+}\right)$and nutrient deficiency (nitrogen, phosphorus, and potassium). The $\mathrm{P}$ concentration in agronomy crops in the field decreases with increased salinity. Salinity decreases $\mathrm{P}$ concentration in crop tissues; elsewhere, salinity increases $\mathrm{P}$ or does not affect it. It is not surprising that differences between studies occur because $P$ concentrations vary significantly in different experiments, and other nutritional interactions may coincide.

The increased salt concentration leads to the accumulation of toxic ions such as $\mathrm{Cl}^{-}$and, in particular, $\mathrm{Na}^{+}$in the cytosols. Several studies have shown that the concentration of $\mathrm{K}^{+}$in crop tissue decreases along with increased salinity of $\mathrm{NaCl}^{-}$. The decrease in $\mathrm{K}^{+}$content in crops by $\mathrm{Na}^{+}$is a competitive process. Salinity decreases the accumulation of $\mathrm{K}^{+}$on leaves (Manchanda \& Garg 2008). The adverse effect of salinity on crops is associated with high water osmotic pressure, the imbalance between $\mathrm{Na}$ ions with $\mathrm{K}, \mathrm{Ca}, \mathrm{Mg}$. Moreover, it is also associated with decreased absorption of N and P (Grattan \& Grieve 1998). In general, salinity reduces the accumulation of $\mathrm{N}$ in crops. This is because a decrease in nitrate concentration mainly accompanies the increase in absorption and accumulation of chloride (Garg et al. 1993).

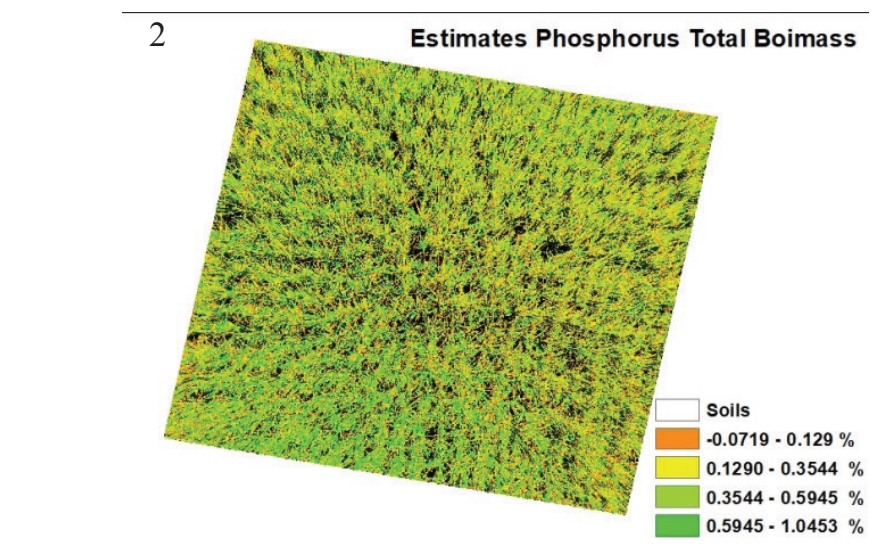

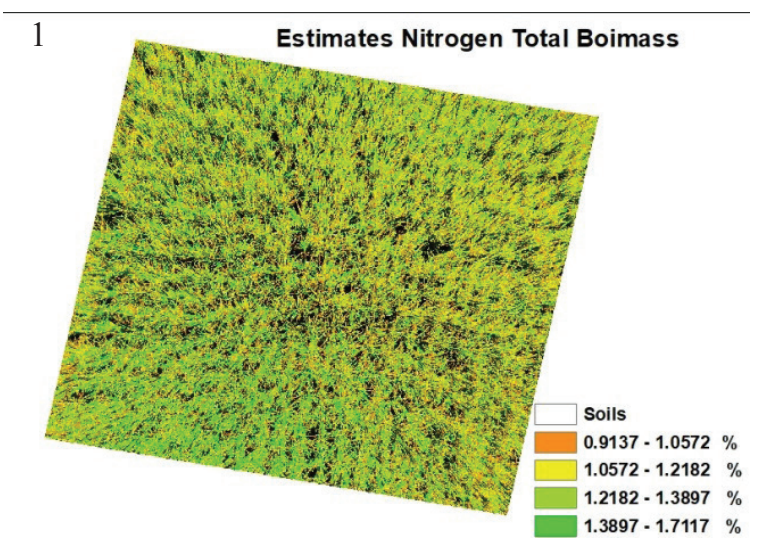

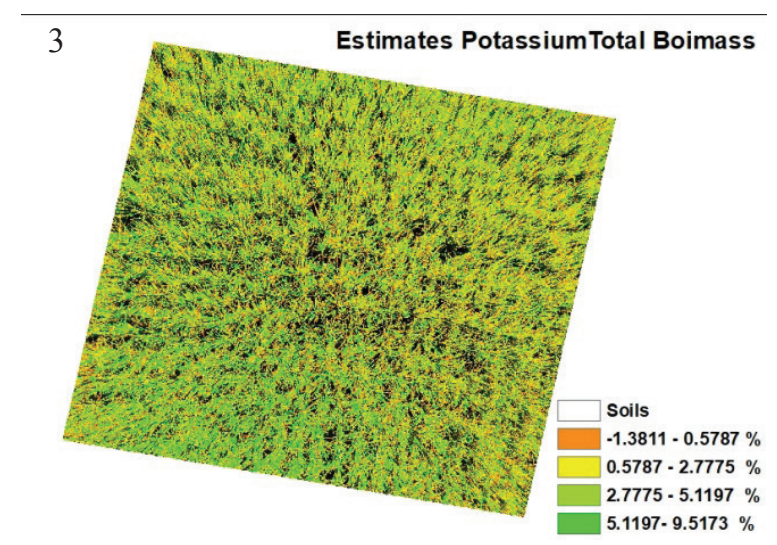

Figure 7. Results of aerial photo estimate nitrogen (1), phosphorus (2), and potassium (3) total biomass rice crops from the smartphone camera 
The diversity of soil salinity is affected by the influence of the source of soil salinity, namely seawater in coastal areas. Thus, the observation point 1a to $10 \mathrm{a}$ and $1 \mathrm{~b}$ to $10 \mathrm{~b}$ describe salinity variability from low to high. Marwanto et al. (2009) explained that the closer to the saline source (coastal), the salinity increases. The digital signal processing is obtained by making use of the characteristic wavelength of the reflected leaves. The smartphone camera sensors can measure, analyse, monitor a condition, and then ' $r$ ' EC and changes in its surroundings. Several sensors on a smartphone camera include ambient light sensors, temperature, and humidity sensors (Maulana \& Setiawan 2018). The smartphone camera is an active detection example that provides its energy source to illuminate targets and uses sensors to measure reflection energy by calculating the reflection angle or time required to recover energy. Some of the smartphone cameras utilize visible RGB (red, blue, and green) electromagnetic waves. Partially, RGB does not affect salinity; the digital number (DN) used is a combination of RGB. The results of the smartphone photo camera refer to the RGB image. The smartphone DN extraction value is obtained from the total RGB value in pixels (RGB combination). A combination of RGB values (red, green, and blue) of aerial photos combine the three primary colours, resulting in various colours in one (Santoso \& Handoyo 2015).

The development of technology in various fields impacts digital image processing, one of them is on smartphones. Smartphones have many features, such as digital image capture (Budiman et al. 2019). A digital image is composed of a collection of dots called pixels to form a digital photo. Smartphones are operated by a Linux-based operating system that includes an operating system, middleware, and applications (Safaat 2011), more than $80 \%$ of smartphone users. Smartphones include operating systems with open source licenses that everyone can use freely to support daily activities and work, including in agriculture (Setiawan \& Herdianto 2018). The use of smartphone cameras is one of the developments of satellite and drone imagery. The advantages are good image quality and can to be arranged and easy to carry everywhere and the results are fast, there are menus such as brightness, sharpen, smooth, and edge detection (Adiyat 2013).
The most significant salinity factor in Jabon is the geographical position of Sidoarjo, which is on the seafront. Salinity as the most significant factor causes a decrease in nitrogen, phosphorus, and potassium in rice crops in Jabon. Meanwhile, other factors such as soil texture, plant varieties, and suboptimal management are less influential than the effect of salinity. Salinity affects soil texture, soil structure, and uptake of plant nutrients. With high salinity values, the availability of plant nutrients is deficient, so that the macronutrient of rice has decreased.

\section{LIMITATIONS AND PROBLEMS IN THE FIELD}

Aerial photos taken using a long stick with a smartphone camera are not used for large land due to the viewing angle. If the entire expanse of the rice field in the photo with a camera using a long stick, then some land will be photographed from the side. Aerial photography is affected by sunlight, brighter cross-sections, reflections of light from rice fields, and shadows in aerial photographs (such as a long stick). Taking photos needs to ensure good weather conditions. Avoid taking pictures when the sky is cloudy or the sun is scorching.

The pick-up is also affected by the area of the rice field map. As in transacts 2, observation points 1 and 2 have a small map width so that the outer part of the map is visible on the aerial photos. Choose a site with a large rice field map. Because of the remote location, it cannot be done for extrapolation to the other place. However, it can be overcome by the interpolation tool in ArcGIS software. One of them is Raster Calculator Tool using a math operation. This tool will calculate each pixel using an expression/ algorithm (Rogers \& Staub 2013). The smartphone camera device used in this study cannot connect with other smartphone cameras or remote control. It can be seen the accuracy of aerial photo-taking. So it uses a timer, then it must be repeated in lifting the long stick. Use a smartphone that supports remote control applications.

The variety and age of rice crops in the field vary considerably at each observation point, allowing variations in rice plants' appearance. The location is determined by trying to make the variety and age of the rice crop more uniform. The optimal age of rice crops used for shooting is in the vegetative phase 2 because it produces a better image (Mosleh 
et al. 2015). In processing aerial photos using the smartphone camera, the extraction is still in composite data. Because it is done manually, the height is not standardized. Even though the gimbal has been installed, the shock when taking also affects the shooting results. A sampling at four corners and one center may be fewer DN and chlorophyll samples of rice crops. Aerial photo processing using a smartphone camera extraction can be done by programming to get a $\mathrm{DN}$ value that includes all pixels or can do orthophoto, then apply a zonal function. In taking aerial photos using a smartphone camera, the handling and height must be the same as the effective area and more stable in the shooting.

\section{CONCLUSIONS}

The content of soil macronutrients (nitrogen, phosphorus, and potassium) significantly affects the rice crop biomass. In saline soils, the availability of these macronutrients is reduced, problematic and hampered. Estimating macronutrient content using a terrestrial camera is an effort to identify nutrient deficiencies early. The macronutrient content has a strong effect on the digital number of smartphone camera values. It has a positive regression (nitrogen, phosphorus, and potassium) of $0.84,0.70$, and 0.70 . This result means that the higher the saline indicator's value, the lower the nitrogen, phosphorus, and potassium values in rice crops. A smartphone camera (terrestrial) can monitor salinity stress's impact on reducing macronutrients (nitrogen, phosphorus, and potassium) in rice crops. The reliability test results of an aerial photo's digital number value through a smartphone camera have a smaller t-count value than the t-table. The estimated value is not significantly different from the actual data, so the aerial photo's digital number value through the smartphone camera can be applied to guess the macronutrients nitrogen, phosphorus, and potassium rice crops and salinity indicators.

Acknowledgements. The author would like to thank the Faculty of Agriculture Universitas Brawijaya who has supported research activities through the 2020 LPPM UB Beginner's grant.
Disclosure statement. The authors declare no conflict of interest.

\section{REFERENCES}

Adiyat, I. (2013). Flash-based digital image processing application on mobile devices. Pontianak: Universitas Tanjungpura, $49 \mathrm{p}$.

Ahmed, M.F. and M. Z. Haider. (2014). Impact of salinity on rice production in the south-west region of Bangladesh. Environmental Science an Indian Journal, 9(4), 136-141.

Al-Karaki, G.N. (2000). Growth, water use efficiency and sodium and potassium acquisition by tomato cultivars grown under salt stress. Journal Plant Nutrition, 23, 1-8. DOI:10.1080/01904160009381992.

Amran, M.B., Sari, N.K.E., Setyorini, D.A., Wahyu, Y., Widiani, D. and Irnameria, D. (2015). Soil quality analysis of Sawarna Beach, Lebak Regency, Banten Province. Proceedings of the National Symposium on Science Innovation and Learning, 8.

Amri, M.M. and Sumiharto, R. (2019). Nitrogen, phosphorus, potassium measurement system with local binary pattern and regression analysis. IJEIS (Indonesian Journal of Electronics and Instrumentation Systems), 9(2), 107. DOI:10.22146/ijeis.34132.

Astika, I.W., Suud, H.M., Setiawan, R. P.A., Syuaib, M.F. and Solahudin, M. (2011). Estimation of rice productivity with image processing taken from mini airplanes. National Seminar PERTETA, 106-112, http://repository.ipb.ac.id/ handle/123456789/68618, Mechanical \& Biosystem Engineering [358].

Bernardi, A.C. de C., Grego, C.R., Andrade, R.G., Rabello, L.M. and Inamasu, R.Y. (2017). Spatial variability of vegetation index and soil properties in an integrated crop-livestock system. Revista Brasileira de Engenharia Agrícola e Ambiental, 21(8), 513-518. DOI:10.1590/1807-1929/agriambi.v21n8p513-518.

Banyo, Y.E., Nio, A.S., Siahaan, P. and Tangapo, A.M. (2013). Rice leaf chlorophyll concentration during water deficiency induced with polyethylene glycol. Jurnal Ilmiah Sains, 13(1), 1-8. DOI:10.35799/jis.13.1.2013.1615.

Bewick, V., Cheek, L. and Ball, J. (2003). Statistics review 7: Correlation and regression. Critical Care, 7(6), 451. DOI:10.1186/cc2401.

Bray, R.H. and Kurtz, L. (1945). Determination of total, organic, and available forms of phosphorus in soils. Soil Science, 59(1), 39-46.

Bremner, J.M. (1996). Nitrogen-total. Methods of Soil Analysis: Part 3 Chemical Methods, 5, 1085-1121. DOI:10.2136/ sssabookser5.3.c37.

Budiman, A., Utomo, P. and Rahayu, S. (2019). Development of applications for early detection of rice pest attacks based on android. Journal of Applied Abdimas, 4(1), 33-39. DOI:10.25273/jta.v4i1.3805.

Central Statistics Agency (2020). Harvest area, production, and rice productivity by province $2018-2019$. Retrieved from the Central Bureau of Statistics: https://www.bps.go.id/subject/53/tanamanpangan.html\#subjekViewTab.

Climate-data.org. (2010). Climate data for cities worldwide. Retrieved from https://en.climate-data.org/.

Darwish, E., Terterink, C., Khalil, M., El-Shihy, O. and Munnik, T. (2009). Phospholipid signaling responses in salt-stressed rice leaves. Plant and Cell Physiology, 50(5), 986-997. DOI:10.1093\%2Fpcp\%2Fpcp051. 
Dell, M. (2009). GIS analysis for applied economists. Department of Economics, Massachusetts Institute of Technology

Djuwansah, M. (2013). Sodium status in polluted soil by textile industry waste in Rancaekek, Bandung Regency. Journal of Soil and Climate, 37(1), 10. DOI:10.21082/jti. v37n1.2013.25-34.

Efendi, R. (2020). Design and build augmented reality applications for android-based detection of medicinal plants. Journal of IKRA-ITH Informatics, 4(1), 11.

Fahmizal, F., Dewantama, G.Y., Pratama, D.B., Fathuddin, F., and Winarsih, W. (2018). Design a camera stabilizer system (gimbal) with fuzzy logic for photo and video capture. Journal of Information Technology and Computer Science, 5(3), 277-286. DOI:10.25126/jtiik.201853785.

Flowers, T.J. and Flowers, S.A. (2005). Why does salinity pose such a difficult problem for plant breeders? Agricultural Water Management, 78, 15-24. DOI:10.1016/j.agwat.2005.04.015.

Garg, B., Vyas, S., Kathju, S., Lahiri, A., Mali, P. and Sharma, P. (1993). Salinity-fertility interaction on frowth, mineral composition and nitrogen metabolism of Indian mustard. Journal of Plant Nutriotion, 16, 1637-1650. DOI:10.1080/01904169309364639.

Grattan, S.R. and Grieve, C.M. (1992). Mineral element acquisition and growth response of crops grown in saline environments. Agriculture, Ecosystems \& Environment, 38(4), 275-300. DOI:10.1016/0167-8809(92)90151-Z.

Grattan, S.R. and Grieve, C.M. (1998). Salinity-mineral nutrient relations in horticultural crops. Scientia Horticulturae, 78(1-4), 127-157. DOI:10.1016/S0304-4238(98)001927.

Gunita, M.H., Andri, S. and Bandi, S. (2013). Mobile GISbased digital map location marker application on android smartphone. Journal of Geodies, 2(4), 26-39.

Gupta, S. and Sharma, S. (1990). Response of crops to high exchangeable sodium percentage. Irrigation Science, 11(3), 173-179. DOI:10.1007/BF00189455.

Iswari, A.R., Hani'ah, H., dan Nugraha, A.L. (2016). Analysis of rice production fluctuations due to the effect of drought in Demak Regency. Journal of Geodesy Diponegoro University, 5(4), 80404.

Kementerian Pertanian (2019). Data for the last five years of rice production and harvest area. Jakarta: Ministry of Agriculture Republic of Indonesia.

LAPAN. (2015). Guidelines for monitoring rice plant growth phase using remote sensing satellite data. LAPAN, Jakarta: Center for Remote Sensing Utilization of the National Aeronautics and Space Institute, pp. 2-5.

Lubis, R.S. 2011. Estimation of correlation between soil characteristics and carbon stock in secondary forest. Tropical Silviculture Journal, 3(1), 78.

Manchanda, G. and Garg, N. (2008). Salinity and its effects on the functional biology of legumes. Acta Physiologiae Plantarum, 30(5), 595-618. DOI:10.1007/s11738-008-0173-3.

Mardiansyah, M., Palupi, T. and Maulidi, M. (2018). Response of several local rice varieties to salinity stress in the nursery phase. Agricultural Student Science Journal, 7(3), 1-9.

Marsoedi, D., Pusat P.T., Widagdo, A., Dai, J., Suharta, N., Darul, S.W.P., Hardjowigeno, S., Hof, J., \& Jordens, E.R. (1997). Guidelines for landform classification. Puslittanak, Bogor: Center for Soil and Agroclimate Research, 33p.

Marwanto, S., Rachman, A., Erfandi, D. and Subiksa, I.G. (2009). Soil salinity level in intensive paddy fields in Indramayu Regency, West Java. Bogor: Soil Research Institute, pp. $28-34$.

Maulana, S.H. and Setiawan, E.B. (2019). Utilization of sensors on android smartphones for plant nursery recommenda- tions. ULTIMATICS: Journal of Informatics Engineering, 10(2), 85-92. DOI:10.31937/ti.v10i2.957.

Monica, N., Vidican, R., Rotar, I., Stoian, V., Pop, R. and Miclea, R. (2014). Plant nutrition affected by soil salinity and response of rhizobium regarding the nutrients accumulation. BioFlux; ProEnvironment, 7, 71-75.

Montolalu, C. and Langi, Y. (2018). The effect of basic computer and information technology training for teachers with paired t-test (Paired Sample T-Test). D'CARTESIAN, 7(1), 44-46. DOI:10.35799/dc.7.1.2018.20113.

Motamed, M., Asadi, K.R. and Amiri, E. (2008). Response of high yielding rice varieties to $\mathrm{NaCl}$ salinity in greenhouse circumstances. African Journal of Biotechnology, 7(21), $3866-3873$.

Mosleh, M.K., Hassan, Q.K. and Chowdhury, E.H. (2015). Application of remote sensors in mapping rice area and forecasting its production: A review. Sensors, 15(1), 769-791, DOI:10.3390/s150100769.

Muñoz, J.D. and Kravchenko, A. (2011). Soil carbon mapping using on-the-go near infrared spectrossalinity, topography and aerial photographs. Geoderma, 166(1), 102-110. DOI:10.1016/j.geoderma.2011.07.017.

Muyassir, M. (2012). Spacing effect of plantation, age and number of seeds on yield of rice (Oryza sativa L.). Journal of Land Resource Management, 1(2), 207-212.

Nurgayah, W. and Irawati, N. (2017). The relationship between chlorophyll-A and physicochemical parameters in the waters of the village of Tanjung Tiram, North Moramo District, South Konawe Regency. Sapa Laut, 2(4), 97-102. DOI:10.33772/jsl.v2i4.3817.

Pardo, J. (2010). Biotechnology of water and salinity stress tolerance. Current Opinion in Biotechnology, 21(2), 185-196. DOI:10.1016/j.copbio.2010.02.005.

Prabowo, R.Y., Rahmadwati, R. and Mudjirahardjo, P. (2018). Classification of nitrogen content based on leaf color through color clustering using fuzzy $\mathrm{C}$ means and hybrid PSO K-means methods. EECCIS Journal, 12(1), 1-7.

Putra, A.N. and Nita, I. (2020). Reliability of using high-resolution aerial photography (red, green and blue bands) for detecting available soil water in agricultural land. Journal of Degraded and Mining Lands Management, 7(3), 2221-2232. DOI:10.15243/jdmlm.2020.073.2221.

Putri, R.E., Yahya, A., Adam, N.M. and Aziz, S.A. (2016). Variability of rice yield with respect to crop health. Jurnal Teknologi, 78, 1-2. DOI:10.11113/jt.v78.7272.

Rachman, A., Dariah, A. and Sutono, S. (2018). Management of high-salt saline rice fields. Jakarta: IAARD Press, pp. $20-48$.

Rayes, M.L. (2007). Land Resource Inventory Method. Yogyakarta: ANDI Yogyakarta.

Rhoades, J., Manteghi, N., Shouse, P. and Alves, W. (1989). Soil electrical conductivity and soil salinity: New formulations and calibrations. Soil Science Society of America Journal, 53(2), 433-439. DOI:10.2136/sssaj1989.03615995005300020020x.

Robbins, C.W. (1984). Sodium adsorption ratio-exchangeable sodium percentage relationships in a high potassium saline-sodic soil. Irrigation Science, 5(3), 173-179. DOI:10.1007/BF00264606.

Rogers, S.R. and Staub, B. (2013). Standard use of geographic information system (GIS) techniques in honey bee research. Journal of Apicultural Research, 52(4), 1-48. DOI:10.3896/IBRA.1.52.4.08.

Royston, P. (1992). Approximating the shapiro-wilk W-test for non-normality. Statistics and Computing, 2(3), 117-119. DOI:10.1007/BF01891203

Ruminta, R. (2016). Analysis of decreasing production of rice 
due to climate change in Bandung district West Java. Kultivasi, 15(1), 37-45.

Safaat, H. (2011). Androids; android based smartphone and tablet PC mobile application programming. Bandung: Informatics, $49 \mathrm{p}$.

Santoso, S. and Handoyo, E.D. (2015). The combination of using the Color model in detecting the location of the lips in color digital images. Journal of Informatics and Information Systems Engineering, 1(2). DOI:10.28932/jutisi.v1i2.574.

Sayed, H.E. and Sayed, A.E. (2013). Exogenous application of ascorbic acid for improve germination, growth, water relations, organic, and inorganic components in tomato (Lycopersicum esculentum Mill.) plant under salt-stress. New York Science Journal, 6(10), 123-139.

Sembiring, H. and Gani, A. (2010). Adaptation of rice varieties on tsunami affected soils. Jakarta: Center for Rice Research. Retrieved from www.dpi.nsw.gov.au/.

Setiawan, E.B. and Herdianto, R. (2018). The use of android smartphones as a tool for analysis of nitrogen requirements in rice plants. National Journal of Electrical Engineering and Information Technology (JNTETI), 7(3), 273-280. DOI:10.22146/jnteti.v7i3.435.

Simanungkalit, K., Damanik, M.R.S. and Lubis, D.P. (2019). Optimization of unmanned aerial vehicle (UAV) aerial photography as remote sensing learning media. Tunas Geografi, 8(1), 45-58. DOI:10.24114/tgeo.v8i1.15507.

Sipayung, R. (2003). Salt stress and plant tolerance mechanisms. Medan: University of Northern Sumatra, pp.1-6.

Soussi, M., Ocana, A. and Lluch, C. (1998). Effects of salt stress on growth, photosynthesis and nitrogen fixation in chickpea (Cicer arientinum L.). Journal of Experimental Botany, 49(325), 1329-1337. DOI:10.1093/jxb/49.325.1329.

Soil Survey Staff. (2014). Key soil taxonomy, twelfth edition. USA: United States Department of Agriculture, Natural Resources Conservation Service, pp. 135-138.

Suhartini, T. and Zulchi, T. (2018). Tolerance of Local Rice Germplasm to Salinity. Agroecotechnology Online Jour- nal, 2, 1196p.

Suryana, H. (2018). Design 3-axis gimbal as camera stabilizer while driving based on Proportional, Integral, Derivative (PID) control system. Bandung: UIN Sunan Gunung Djati. $113 \mathrm{p}$.

Syauqani, A., Subiyanto, S. and Suprayogi, A. (2017). The effect of variations in flight height using the unmanned aerial vehicle (UAV) quadcopter DJI PHANTOM 3 pro on orthophoto map making (case study at Diponegoro University). Journal of Geodesy at Diponegoro University, 6(1), $249-257$.

USDA, A. (2020). United States Department of Agriculture (USDA). Retrieved from https://www.usda.gov/topics/ data/.

Utama, M.H. (2015). Rice cultivation on marginal land: tips to increase rice production. Yogyakarta: CV. ANDI OFFSET, pp. 105-208.

Vadas, P., Mallarino, A. and McFarland, A. (2006). The importance of sampling depth when testing soils for their potential to supply phosphorus to surface runoff. Extension Fact Sheets, 1 .

Widada, S. (2007). Symptoms of sea water intrusion in the coastal area of Pekalongan City. Protobiont, 12(8), $101-105$.

WorldAgriculturalProduction.com. (2020). Production rice world 2020. Retrieved from http://www.worldagriculturalproduction.com/crops/rice.aspx.

Zakiyah, Z.N., Rahmawati, C. and Fatimah, I. (2018). Analysis of phosphorus and potassium levels in organic fertilizer in the integrated Laboratory of Jombang District Agriculture Office. Indonesian Journal Of Chemical Research, 3(2), 38-48. DOI:10.20885/ijcr.vol3.iss2.art1.

Received: February 2, 2021 Accepted: June 2, 2021 